\title{
Nodulation, Leghaemoglobin Content and Yield of Greengram as Influenced by New Generation Early Post Emergence Herbicide Combinations
}

\author{
S. Poornima*, Y. Siva Lakshmi, T. Ram Prakash, A. Srinivas and L. Venkata Krishnan \\ Division of Agronomy, Indian Agricultural Research Institute, New Delhi 110 012, India \\ *Corresponding author
}

A B S T R A C T

\begin{tabular}{|l|}
\hline Ke y w o r d s \\
Early Post- \\
emergence, \\
Greengram, Root \\
nodules, \\
Leghaemoglobin \\
content.
\end{tabular}

A field experiment was conducted during kharif 2015 at college farm, College of Agriculture, Rajendranagar, Hyderabad to study the impact of new generation herbicide combinations on nodulation and leghemoglobin content of greengram (Vigna radiata L.) in South Telangana. The experiment was laid out in Randomized Block Design consisted of 11 treatments and 3 replications viz. pendimethalin @ $1.0 \mathrm{~kg} / \mathrm{ha}$ as pre-emergence, pendimethalin followed by imazethapyr @ $75 \mathrm{~g} / \mathrm{ha}$ as post-emergence (at 2-4 leaf stage), imazethapyr @75 g/ha' chlorimuron ethyl @9 g/ha, quizalofop ethyl @ 50 g/ha + imazethapyr@75 g/ha, imazethapyr+imazamox @70 g/ha, propaquizafop @ $50 \mathrm{~g} / \mathrm{ha}+$ imazethapyr @75 g/ha, haloxyfop-p-methyl @ $135 \mathrm{~g} / \mathrm{ha}+$ imazethapyr @ $75 \mathrm{~g} / \mathrm{ha}$, cycloxydim@80 g/ha + imazethapyr @75 g/ha, hand weeding at 20 and 40 DAS and unweeded control. The herbicide combinations were applied at 12-15 DAS. The results revealed that combinations of haloxyfop-p-methyl @ $135 \mathrm{~g} / \mathrm{ha}+$ imazethapyr @ $75 \mathrm{~g} / \mathrm{ha}$, and quizalofop ethyl @ $50 \mathrm{~g} / \mathrm{ha}+$ imazethapyr @ $75 \mathrm{~g} / \mathrm{ha}$ applied 12-15 DAS were found promising for getting higher productivity without affecting the nodulation.

\section{Introduction}

Greengram is the third important pulse crop of India in terms of area 3.77 millon ha and production 1.52 million tonnes (DAC, 2015). It serves as a vital source of vegetable protein (19.1-28.3\%) and vitamins (Singh et al., 2015). Weed infestation is one of the major constraints in greengram cultivation and causes 50 to $90 \%$ yield loss (Kumar et al., 2006). Being a short statured crop it is invaded by a large number of fast growing weeds at initial stage. Hand weeding is effective in controlling the weeds but unavailability of labor and continuous rainfall in rainy season does not permit it to operate timely. It is also time consuming and costly. Therefore, chemical control of weed forms an excellent alternative to manual as well as mechanical weeding and provides weed-free environment from emergence up to 30-35 days (Dungarwal et al., 2003). However, the adverse impact of herbicides on nodulation in legumes was reported (Ahemad, 2012).

Impact of herbicides was evident in the form of reduced number of total and active nodules. The information regarding impact of herbicides on nodulation is scanty in greengram. Hence, the study was under taken to find out the most effective early postemergence herbicide combinations for getting higher yield without affecting the nodulation in greengram. 


\section{Materials and Methods}

\section{Study area}

The present experiment was carried out during Kharif, 2015 at the college farm, College of Agriculture, Rajendranagar, Hyderabad. The farm is geographically situated at an altitude of $542.6 \mathrm{~m}$ above mean sea level (MSL) and $78^{\circ} 28^{\prime} \mathrm{E}$ longitude and $17^{\circ} 19^{\prime} \mathrm{N}$ latitude and falls under the Southern Zone of Telangana State. The soil of the experimental site was classified as sandy loam in texture, neutral in reaction, low in organic carbon and available nitrogen, high in available phosphorus and potassium.

\section{Treatments and experimental design}

Eleven treatments viz. pendimethalin @ 1.0 $\mathrm{kg} / \mathrm{ha}$ as pre-emergence, pendimethalin followed by imazethapyr @ $75 \mathrm{~g} / \mathrm{ha}$ as postemergence (at 2-4 leaf stage), imazethapyr @ 75 g/ha' chlorimuron ethyl @ 9 g/ha, quizalofop ethyl @50 g/ha + imazethapyr @ 75 g/ha, imazethapyr + imazamox @ $70 \mathrm{~g} / \mathrm{ha}$, propaquizafop@50g/ha + imazethapyr @ 75 g/ha, haloxyfop-p-methyl @ 135 g/ha + imazethapyr@75 g/ha, cycloxydim@80 g/ha + imazethapyr @ 75 g/ha, hand weeding at 20 and 40 DAS and unweeded control. The herbicide combinations were applied at 12-15 DAS. The experiment was laid out in Randomized Block Design with replications. The crop variety 'MGG-295' was sown on $25^{\text {th }}$ July, 2015 at a spacing of $30 \mathrm{~cm} \times 10 \mathrm{~cm}$ and fertilized with 20: 40: $30 \mathrm{~kg} \mathrm{~N}, \mathrm{P}_{2} \mathrm{O}_{5}$ and $\mathrm{K}_{2} \mathrm{O} / \mathrm{ha}$. All the herbicides were applied with knap sack sprayer fitted with flat-fan nozzle.

\section{Plant sample collection and analysis}

The roots were carefully washed to remove the adhering soil particles and the numbers of nodules were counted at 30,38 and 45 DAS. The nodules were collected and shade dried.
Later oven dried at $65^{\circ} \mathrm{C}$ for 24 hours and the final dry weights were recorded. The leghaemoglobin content in fresh nodules recovered from the root system of greengram was quantified calorimetrically as haemochromogen by the method of Hartree $e t$ al., (1955) at 30, 38 and 45 days after sowing.

\section{Yield estimation}

The experimental crop was finally harvested on 10 September 2015 after taking 2 picking of pods. The crop was sun-dried for 3 days and manual threshing was done separately for each experimental plot. The yield from all the pickings and finally harvested and threshed crop was combined to arrive at yield/ha. The analysis of variance of data was carried out using OPSTAT and significance was tested by 'F-test'.

\section{Results and Discussion}

Number of nodules/plant, dry weight nodules/plant and leghaemoglobin content differed significantly among the treatments and increased with increase in age of the crop at all the growth stages. At 30 days after sowing, significantly higher nodule attributes were recorded with hand weeding at 20 and 40 DAS whereas significantly lower nodule attributes were observed with chlorimuron ethyl at $9 \mathrm{~g} / \mathrm{ha}$ at $12-15$ DAS due to its phytotoxicity. At 38 days after sowing significantly higher number of nodule parameters were observed with hand weeding at 20 and 40 days after sowing which was on a par with haloxyfop-p-methyl + imazethapyr, and quizalofop ethyl + imazethapyr. The trend was similar at 45 DAS too. Higher nodule attributes in hand weeding at 20 and 40 days after sowing at all the growth stages was due to increased aeration of Rhizosphere in disturbed soil condition. The results were in conformity with Raman and Krishnamoorthy (2005) (Table 1). 
Int.J.Curr.Microbiol.App.Sci (2017) 6(12): 2134-2137

Table.1 Effect of early post-emergence herbicides on yield, nodulation and leg haemoglobin content of greengram

\begin{tabular}{|c|c|c|c|c|c|c|c|c|c|c|}
\hline \multirow{3}{*}{ Treatment } & \multicolumn{3}{|c|}{ Nodule (Nos./plant) } & \multicolumn{3}{|c|}{ Dry weight (mg/plant) } & \multicolumn{3}{|c|}{$\begin{array}{l}\text { Leg haemoglobin content } \\
\qquad(\mathrm{mg} / \mathrm{g})\end{array}$} & \multirow{3}{*}{$\begin{array}{l}\text { Seed yield } \\
(\mathrm{kg} / \mathrm{ha})\end{array}$} \\
\hline & 30 & 38 & 45 & 30 & 38 & 45 & 30 & 38 & 45 & \\
\hline & DAS & DAS & DAS & DAS & DAS & DAS & DAS & DAS & DAS & \\
\hline $\begin{array}{l}\text { Pendimethalin @ } 1 \text { kg.ha as pre- } \\
\text { emergence }\end{array}$ & 24.0 & 27.2 & 29.8 & 18.0 & 27.0 & 30.2 & 0.37 & 0.77 & 1.00 & 426 \\
\hline $\begin{array}{l}\text { Pendimethalin @ } 1 \mathrm{~kg} / \mathrm{h} \text { followed by } \\
\text { imazethapyr @ } 75 \mathrm{~g} / \mathrm{ha} \text { as post- } \\
\text { emergence (at } 2-4 \text { leaf stage) }\end{array}$ & 21.0 & 28.2 & 34.1 & 18.1 & 29.0 & 35.0 & 0.39 & 0.81 & 1.03 & 912 \\
\hline Imazethapyr @75 g/ha & 20.3 & 27.2 & 33.4 & 18.0 & 27.7 & 32.6 & 0.38 & 0.78 & 1.01 & 742 \\
\hline Chlorimuron ethyl @ 9g/ha & 9.5 & 14.5 & 15.2 & 12.3 & 12.6 & 15.8 & 0.18 & 0.45 & 0.73 & 224 \\
\hline $\begin{array}{l}\text { Quizalofop ethyl @ } 50 \mathrm{~g} / \mathrm{ha}+ \\
\text { imazethapyr @ } 75 \mathrm{~g} / \mathrm{ha}\end{array}$ & 23.8 & 32.8 & 39.0 & 19.5 & 33.0 & 44.0 & 0.40 & 0.82 & 1.03 & 1008 \\
\hline $\begin{array}{l}\text { Imazethapyr@+imazamox @ } 70 \\
\text { g/ha }\end{array}$ & 20.8 & 27.8 & 33.6 & 18.0 & 28.8 & 34.8 & 0.39 & 0.79 & 1.02 & 900 \\
\hline $\begin{array}{l}\text { Propaquizafop@ @ } 50 \mathrm{~g} / \mathrm{ha}+ \\
\text { imazethapyr @ } 75 \mathrm{~g} / \mathrm{ha}\end{array}$ & 21.0 & 28.2 & 34.2 & 18.5 & 29.3 & 35.4 & 0.40 & 0.81 & 1.03 & 920 \\
\hline $\begin{array}{l}\text { Haloxyfop-p-methyl @ } 135 \text { g/ha + } \\
\text { imazethapyr @ } 75 \text { g/ha }\end{array}$ & 24.2 & 32.9 & 41.2 & 19.5 & 33.8 & 44.7 & 0.40 & 0.83 & 1.04 & 1029 \\
\hline $\begin{array}{l}\text { Cycloxydim @ } 80 \mathrm{~g} / \mathrm{ha}+\text { imazethapyr } \\
\text { @ } 75 \mathrm{~g} / \mathrm{ha}\end{array}$ & 20.0 & 28.2 & 33.2 & 18.0 & 27.0 & 32.0 & 0.37 & 0.79 & 1.01 & 737 \\
\hline Hand weeding at 20 and 40 DAS & 32.3 & 36.4 & 42.8 & 22.6 & 36.5 & 48.6 & 0.48 & 0.95 & 1.19 & 1086 \\
\hline Unweeded control & 15.0 & 23.2 & 26.5 & 15.2 & 25.0 & 30.6 & 0.01 & 0.55 & 0.84 & 425 \\
\hline $\mathrm{S} \mathrm{Em} \pm$ & 0.97 & 1.37 & 1.42 & 0.56 & 1.28 & 1.68 & 0.02 & 0.04 & 0.05 & 28 \\
\hline $\mathrm{CD}(\mathrm{P}=0.05)$ & 2.80 & 3.70 & 4.11 & 1.68 & 3.65 & 4.87 & 0.06 & 0.12 & 0.15 & 82 \\
\hline
\end{tabular}


The seed yield was significantly superior with hand weeding at 20 and $40 \mathrm{DAS}$, and was on a par with haloxyfop-p-methyl at $135 \mathrm{~g} / \mathrm{ha}+$ imazethapyr at $75 \mathrm{~g} / \mathrm{ha}$ applied at $12-15 \mathrm{DAS}$ and quizalofop ethyl at $50 \mathrm{~g} / \mathrm{ha}+$ imazethapyr at $75 \mathrm{~g} / \mathrm{ha}$ applied at $12-15 \mathrm{DAS}$. The combination of early post-emergence herbicides resulted in superior control of weeds leading to higher seed yield. These results corroborate the findings of Kaur et al., (2009) and Raj et al., (2012).

It is concluded that from the above findings it is clearly indicated that the combinations of haloxyfop-p-methyl at $135 \mathrm{~g} / \mathrm{ha}+$ imazethapyr at $\mathrm{g} / \mathrm{ha}$, and quizalofop ethyl at $50 \mathrm{~g} / \mathrm{ha}+$ imazethapyr at $75 \mathrm{~g} / \mathrm{ha}$ applied at 12-15 days after sowing as an early postemergence can be recommended for weed control in greengram in Southern Zone of Telangana for getting higher yield without affecting the nodulation.

\section{References}

Ahemed, M. 2012. A comparative analysis of the growth parameters of different legume crops grown in quizalofop-pethyl applied soils. Insight Botany 2(1): $1-6$.

DAC. 2013. Directorate of Economics and Statistics, Department of Agriculture and Cooperation, Government of India, New Delhi.
Dungarwal, H. S., Chaplot, P. C. and Nagda, B. L. 2003. Chemical weed control in mungbean (Plaseolus radiatus L.). Indian Journal of Weed Science 35: 283-84.

Hartree E. F. 1955. "Haematin compounds". In Modern methods of plant analysis Edited by: Paech, K and Tracey, M V. 197-245. Berlin: Springer-Verlag.

Kaur, G., Brar, H. S. and Singh, G. 2009. Effect of Weed management on weeds, growth and yield of mungbean [Vigna radiata (L.) R. Wilczek]. Indian Journal of Weed Science 41(3 and 4): 228-231.

Kumar, A., Malik, Y. P. and Yadav, A. 2006. Weed management in mungbean. Journal of Research 36 (2): 127-29.

Raj, V. C., Patel, D. D., Thanki, J. D and Arvadia, M. K. 2012. Effect if integrated weed management on weed control and productivity of greengram (Vigna radiata). BIOINFOLET. 9 (3): 392-396.

Raman, R., and Krishnamoorthy, R. 2005. Nodulation and yield of mungbean Vigna radiata (L.) influenced by integrated weed management practices. Legume Research 28(2): 128-130.

Singh, G., Kaur, H., Aggarwal, N. and Sharma, P. 2015. Effect of herbicides on weeds growth and yield of greengram. Indian Journal of Weed Science 47(1): 38-42.

\section{How to cite this article:}

Poornima, S., Y. Siva Lakshmi, T. Ram Prakash, A. Srinivas and Venkata Krishnan, L. 2017. Nodulation, Leghaemoglobin Content and Yield of Greengram as Influenced by New Generation Early Post Emergence Herbicide Combinations. Int.J.Curr.Microbiol.App.Sci. 6(12): 2134-2137. doi: https://doi.org/10.20546/ijcmas.2017.612.244 